\title{
THINKPIECE
}

\section{LAW AS A NETWORK STANDARD}

\section{DAN L. BURK ${ }^{\dagger}$}

\begin{abstract}
The problem of global information flows via computer networks raises issues of competition, interoperability, and standard-setting parallel to those in the analysis of technical standards. Uniform standards, whether technical or legal, give rise to a constellation of positive and negative network effects. As a global network based upon the "end to end" principle of interoperability, the Internet mediates between different, otherwise incompatible computing platforms. To the extent that law and technological "code" may act as substitutes in shaping human behavior, the Internet similarly mediates between different, otherwise incompatible legal platforms. Much of the legal and social controversy surrounding the Internet stems from the interconnection of such incompatible legal systems. As with technical systems, problems of incompatibility may be addressed by the adoption of uniform legal standards. This, however, raises legal standard-setting problems similar to those seen in technical standard setting, where the standard may be "tipped" in favor of dominant producers. In particular, if law is considered a social product, the benefits of interjurisdictional competition and diversity may be lost as a single uniform legal standard dominates the market for law.
\end{abstract}

\footnotetext{
Visiting Professor, Cornell Law School; Oppenheimer, Wolff \& Donnelly Professor of Law, University of Minnesota.

Jointly reviewed and edited by YALE JOURNAL OF LAW \& TECHNOLOGY and INTERNATIONAL JOURNAL OF COMMUNICATIONS LAW \& POLICY.
} 


\section{INTRODUCTION}

Global information flows are re-shaping the international information landscape, channeled from nation to nation through the new outlets provided by global computer networks. Such movement of information between jurisdictions invites conflicting application of local regulations over advertising, intellectual property, hate speech, personal data, and other communicative content. Understanding the role of the Internet in this context is crucial to understanding the phenomenon of transborder information exchanges, as the Internet both forms an active conduit for much of this information flow, and provides a case study for understanding information flows outside the network.

Thus, formulating an approach to regulation and control of the Internet provides a window to conceptualizing the regulation and control of information flows generally. To a greater extent than any previous communications medium, the Internet facilitates the interconnection of potentially incompatible law regimes. The natural response to such incompatibility is to seek harmonization or centralization of legal standards at a supranational level. The case for harmonization or centralization of regulation at the international level is in many instances compelling. However, enthusiasm for an international regulatory approach must be tempered by caution over the potential costs and drawbacks of centralized hierarchical control. Improperly applied, international Internet regulation threatens to negate the characteristics that make the network valuable, and could in fact eliminate the very benefits that network regulation is intended to preserve.

The cure may therefore be as bad as the disease; at a minimum it carries with it a variety of troublesome results. In this essay, I briefly discuss two related cautionary models implicated by the argument for international regulation. I shall argue that Internet regulation at an international level may be conceived as a standards setting problem, presenting, at a multi-national level the same dangers and benefits of uniformity, competition, and strategic behavior familiar from analyses of technical standards-setting. This approach arises from the conceptualization of law as a product, and from potential for interchanging law and technology as regulatory methods.

I begin by reviewing the interjurisdictional competitive literature analyzing law as a product. I then extend the basic concepts of that model to discuss implications of international regulation in light of network effects in the market for law. I conclude that these models point to only a limited and particularized case for international regulation in order to preserve the benefits of decentralized innovation in law. Consequently, in any given instance, the case for harmonized international regulation must be evaluated according to its potential for curtailing the competitive benefits of localized regulatory innovation.

\section{LAW AS A PRODUCT}


The problem of transborder data regulation implicates the economic models developed to analyze interjurisdictional competition. In 1956, Charles Tiebout published his now classic paper modeling local provision of public services on a theory of inter-jurisdictional competition that closely resembles market competition for provision of private goods. ${ }^{1}$ Tiebout theorized that if citizens are free to migrate between jurisdictions, competition for desirable citizen immigrants will arise. Local communities will offer to potential immigrants the most attractive packages of goods and services at the lowest tax rate possible. Similarly, migrants will relocate to jurisdictions offering the maximum package of public goods at the tax rate that the migrant is willing to pay. Local communities may even tailor their offerings to appeal to particular types of immigrants, and immigrants would be expected to sort themselves out into groups of similar means and tastes by jurisdiction. ${ }^{2}$

Under Tiebout's approach, the production of local public goods and services might thus resemble the production of private goods in a competitive market: competitive pressure from other jurisdictions will prevent any given jurisdiction from offering too much or too little in the way of public services. ${ }^{3}$ Jurisdictions that offer too much will experience an influx of immigrants from less generous jurisdictions; jurisdictions that offer too little will experience an exodus to more generous jurisdictions. Migration in or out of the jurisdiction will continue until parity with competing jurisdictions is reached. ${ }^{4}$ These forces therefore act as a check on over-production or under-production of local public goods. By "voting with their feet," or exiting, citizens force efficiency in allocation of resources to such goods. ${ }^{5}$

Tiebout's insight was quickly expanded to encompass strategic preferences of local governments regarding business firms. Just as in the consumer/citizen model, businesses too may vote with their feet, locating their operations in jurisdictions that offer the most attractive set of local public goods. ${ }^{6}$ This in turn implies that jurisdictions may tailor their offerings to attract businesses, or to attract certain kinds of desirable businesses, or even to repel undesirable businesses. ${ }^{7}$ In this market for business migration, the price of migration may take a variety of forms: jurisdictions may offer anything from tax incentives, land grants, and liability waivers to museums, sports arenas, and public transportation

\footnotetext{
${ }^{1}$ Charles Tiebout, A Pure Theory of Local Expenditures, 64 J. POL. ECON. 416 (1954).

${ }^{2}$ See Martin McGuire, Group Segregation and Optimal Jurisdictions, 82 J. POL. ECON. 112 (1974).

${ }^{3}$ See Joseph Stiglitz, The Theory of Local Public Goods, in Local Provision OF PubliC Services: The Tiebout Model After Twenty-Five Years 17, 18 (George R. Zodrow ed., 1983).

${ }^{4}$ See George J. Stigler, Economic Competition and Political Competition, 13 PubliC CHOICE 91, 93 (1972).

${ }^{5}$ See Dennis Mueller, Public Choice 126-27 (1979).

${ }^{6}$ See Frank H. Easterbrook, Antitrust and the Economics of Federalism, 26 J.L. \& ECON. 23, 28 (1983).

7 See id. at 43; Susan Rose-Ackerman, Does Federalism Matter? Political Choice in a Federal Republic, 89 J. POL. ECON. 152, 157 (1981).
} 
systems. ${ }^{8}$ Jurisdictions compete for desirable business émigrés by offering packages of such benefits.

Local law comprises an important component of each jurisdiction's competitive package. Regulation with economic effects may be tailored to foster and attract certain industries. For example, environmental regulations may be eased in order to lower the operating costs of favored industries. Patent and copyright laws may be strengthened in order to maximize the economic return to industries that innovate. Corporate and partnership laws may be designed to accommodate investment and control structures amenable to certain industries. Indeed, development of desirable law "products" may be even more important to attract and retain high-value businesses activity than it is to attract and retain high-value individuals.

This model therefore suggests that competition for business and for desirable immigrants will prompt jurisdictions to compete with one another to offer the most attractive law "products" - in effect, creating a market for law. Optimally, such competition will tend toward not only the production of law that is differentiated to suit certain business profiles, but also to produce better and more efficient regulation - the threat of losing businesses to another jurisdiction will tend to weed out the inefficient legal regimes. However, it is also possible for this race to the top to become a "race to the bottom." The Tiebout model assumes that jurisdictions are tightly compartmentalized so that no external costs or benefits accrue from the local provision of public services. ${ }^{9}$ If jurisdictions are leaky, then individuals could perhaps enjoy the positive benefits of a neighboring jurisdiction's policy without actually incurring the cost of migrating there. ${ }^{10}$ More significantly, in a world of leaky borders, jurisdictions could lower the costs to local firms by imposing all or part of those costs on neighboring jurisdictions. " "This would serve to attract firms, but not necessarily by generating a net gain in efficiency.

Consequently, in a world of leaky borders, the race to the bottom might best be characterized as a race to externalize - for jurisdictions to seek ways to gain at the expense of their neighbors. Because the externalized costs of such local regulation are imposed upon others, jurisdictions will tend to overspend on law products, offering immigration incentives for which they themselves need not pay. The Internet of course is a source of transborder leakiness, at least for digitized products and for data migration. This raises the concern that the Internet may trigger such races to externalize costs, providing a conduit for local costs to be imposed upon other jurisdictions.

Thus, to take a recent, prominent, and hotly debated example, one possible characterization of the peer-to-peer music file-sharing phenomenon, whereby digitized music, software, and movies are shared via services such as BitTorrent, Kazaa, or similar on-line services, is that

\footnotetext{
${ }^{8}$ See Albert Breton, The Existence and Stability of Interjurisdictional Competition, in COMPETITION AMONG STATES AND LOCAL GOVERNMENTS: EFFICIENCY AND EQUiTy IN AMERICAN FEDERALISM 37, 42 (Daphne A. Kenyon \& John Kincaid eds., 1991).

${ }^{9}$ Robert P. Inman \& Daniel L. Rubinfeld, The Political Economy of Federalism, in Perspectives on Public Cholce: A Handbook 71, 83 (Dennis C. Mueller ed., 1997).

${ }^{10}$ See Stiglitz, supra note 3 at 48.

${ }^{11}$ See Roberta Romano, The Genius of American Corporate Law 5-6 (1993).
} 
suggesting a race to the bottom. Much of the supply of such files comes out of jurisdictions with lax copyright law or lax enforcement; indeed, businesses supplying software for such file-sharing have taken advantage of the attractive incorporation law and legal immunity provided by small and somewhat obscure jurisdictions such as the Pacific island of Vanuatu. Lurking in permissive jurisdictions, these entities free-ride off of the creativity fostered in protective jurisdictions, using the Internet as a conduit to bleed legitimate incentives away from the owners and producers of valuable creative works.

But in branding such a scenario an inefficient "race to the bottom" we must exercise care. Early analyses of incorporation races among jurisdictions in the United States branded this race a "race to the bottom," a race to benefit corporate officers at the expense of shareholders. Later, more careful analyses suggest that it may in fact have been a "race to the top," a competition among jurisdictions to produce the best package of corporate law "products." In making such characterizations, the perspective adopted may dictate the conclusion.

Thus, in our peer-to-peer file sharing example, a rather different story might be told using the same facts: in this version, off-shore encouragement of peer-to-peer entrepreneurship becomes a race to the top, forcing a bloated and complacent U.S. entertainment industry to revise its archaic and outmoded business models. On this view, consumer adoption of digital technology has outstripped the recording industry's sluggish pace of change, creating a gap between consumer demand and the dated products provided by entertainment firms. Peer-to-peer entrepreneurship filled that gap, providing not only innovative distributional services but also models for traditional entertainment firms to emulate. Without the harsh market discipline of file sharing, the authorized music downloading services now beginning to cater to consumer demand might never have been launched.

\section{A. LAW CaRTELS}

Where borders leak, however, undesirable transborder migrations might be curtailed by equalizing the benefits on each side of the border. Jurisdictions might agree to set a uniform standard for their law products, removing the incentive to race to the top or to the bottom. Then, much like a classic private-sector economic cartel, governments that participate in an international agreement may be able to avoid ruinous competition in the market for law as a good. By standardizing the law product, they may succeed in effectively fixing the price for business migration.

Taking copyright as an example in the Internet context, enforcement of high protectionist standards would prevent cartel nations from lowering their price to attract information distributors-that is, so-called pirates. Fixing the price for information distributor migration would in turn allow domestic producers to avoid foreign information competition and engage in monopoly overcharge for information products. ${ }^{12}$ On an international scale,

\footnotetext{
${ }^{12}$ See Easterbrook, supra note 6 at 39.
} 
this type of monopoly overcharge effectively taxes non-producing nations-particularly developing nations - to support the information producers of the developed world. ${ }^{13}$

Such collusive international activity may be highly advantageous to politicians at the national level. ${ }^{14}$ First, through collusion with foreign politicians, domestic politicians can protect themselves against superior foreign law products. Exodus of firms to more attractive regulatory regimes may place domestic politicians and bureaucrats under pressure to streamline local regulation, perhaps at the expense of favored but inefficient rent-seeking constituents. ${ }^{15}$ Such streamlining may, however, be avoided by agreement with foreign counterparts to cooperate in suppressing formulation of more efficient regulation in their respective jurisdictions.

At the same time, local politicians may use an international agreement to deflect domestic voter dissatisfaction over domestic special interest legislation, by characterizing the local protectionist measures as a necessary part of international cooperation. This in essence facilitates intrajurisdictional externalization of regulatory costs: rather than shifting costs to other jurisdictions, costs are shifted to a different constituency within the jurisdiction. ${ }^{16}$ Thus, international collusion may prevent not only exit from correcting political improvidence, but may also suppress the "voice" of internal constituents from prompting correction.

Returning to the example of peer-to-peer technology, we might query whether the active campaign for increased intellectual property protection in the face of widespread file sharing fits this model. Indeed, this characterization suggests that the fierce lobbying and advocacy campaigns waged by the entertainment industries have merely been rentseeking attempts to preserve their current business position by legislative fiat, which may be had for an investment in lobbying activity which less financially burdensome making the sizeable investment necessary to restructure their outmoded business model. If this characterization is correct, elevating the results of such lobbying efforts to the international level only encourages socially inefficient behavior by removing the possibility of more efficient extraterritorial competition.

However, the success of national protectionists, or any other group of price-fixers, requires a stable cartel, and cartels of any sort are notoriously unstable. ${ }^{17}$ Such instability results in part from a sort of "Prisoner's Dilemma" version of the "race to the bottom" effect. Cartels extract monopoly profits by agreeing to restrain output so as to be able to push prices to monopoly levels that would be impossible to maintain if the members engaged in production at competitive levels. Cartel members therefore have a strong incentive to cheat: if a cartel member engages at competitive level production while competitors restrain output, the cheater can reap enormous profits. But since all members of the cartel are tempted

\footnotetext{
${ }^{13} C f$. id. (discussing monopoly overcharge as a form of taxation).

14 See Roland Vaubel, A Public Choice View of International Organization, in THE POLITICAL ECONOMY OF INTERNATIONAL ORGANIZATIONS 32 (Roland Vaubel \& Thomas D. Wilbert eds., 1991).

${ }^{15}$ See Breton, supra note 8, at 39-40.

${ }^{16}$ See Joel P. Trachtman, International Regulatory Competition, Externalization, and Jurisdiction, 34 HARV. INT'L L.J. 47, 57 (1993).

${ }^{17}$ See George J. Stigler, A Theory of Oligopoly, 72 J. POL. ECON. 44 (1977).
} 
by this same possibility, one member is unlikely to be able to cheat without triggering cheating by all the other members, leading back to competitive pricing and loss of the profits that prompted the cheating.

In the case of private economic cartels, a collusive organization is believed to be most feasible and stable where the quality of the product is homogeneous, the price elasticity of demand for the product is low, barriers to entry are high, all suppliers of the product have similar cost functions, and there is a dominant supplier who can act as price-leader. ${ }^{18}$ In the case of international collusion over Internet law "products," several of these requirements may be met by the configuration of participation in law production.

First, it would appear that the universe of law producers on an international scale is largely closed, forming something of a barrier to entry. New nations do not arise with particular frequency, and when they do, the circumstances of their inauguration -- such as revolution or social upheaval -- will likely deter information producers from relocating to take advantage of whatever new law products they choose to offer. Additionally, accumulation of "legal capital" poses a barrier to jurisdictions attempting to enter the law product market. In Roberta Romano's classic analysis of the race to the top for incorporation law in the United States, firms that incorporated in Delaware repeatedly referred to the large body of settled case law on corporations as a reason for incorporating there. ${ }^{19}$ Similarly, nations with a long history of well-developed information law may be especially attractive to information distributors seeking to locate their operations, especially if the jurisdiction sports specialty courts with a high degree of expertise. The certainty offered by a well-developed body of relevant law may in many instances offer greater business value than would relaxed regulation of information distribution. New entrants into the information law market may have their work cut out for them in order to displace the law products of well-established jurisdictions. ${ }^{20}$

Price-leadership or "dominant firm" effects may also be seen in the market for law products. The number of sovereign states is relatively large, but certain nations, particularly the United States, are able to exert considerable diplomatic and economic pressure toward conformity. ${ }^{21}$ By promulgating its copyright and patent law products as a proposed standard for inclusion within the Berne Convention revisions, ${ }^{22}$ or TRIPs trade agreements, ${ }^{23}$ the United States has rather successfully attempted to co-

\footnotetext{
${ }^{18}$ See Vaubel, supra note 14 , at 33.

${ }^{19}$ See Romano, supra note 11 at 258-61, 274-75.

${ }^{20} \mathrm{Cf}$. Romano, supra note 11 at 40 . ("Legal capital is not as easily duplicated by other states...because of the start-up costs in developing precedent and the dynamic precedentbased nature of adjudication by courts.")

${ }^{21}$ Marci A. Hamilton, The TRIPS Agreement: Imperialistic, Outdated, and Overprotective, 29 VAnd. J. TRansnat'L L. 613, 615-16 (1996); J.H. Reichman, Beyond the Historical Lines of Demarcation: Competition Law, Intellectual Property Rights, and International Trade After the GATT's Uruguay Round, 20 BROOK. J. INT'L L. 75, 113 (1993).

${ }^{22}$ See Pamela Samuelson, The U.S. Digital Agenda at WIPO, 37 VA. J. INT'L L. 369, 374 75 (1997). The Berne Convention is an international treaty governing copyright and related rights. Berne Convention for the Protection of Litrary and Artistic Works, Sept. 9, 1886, as last revised at Paris, July 24, 1971 (amended 1979), 828 U.N.T.S. 221.

${ }^{23}$ Agreement on Trade-Related Aspects of Intellectual Property Rights, Apr. 15, 1994, Marrakesh Agreement Establishing the World Trade Organization, Annex 1C, LEGAL
} 
ordinate the international market for such law products. The European Union has taken much the same approach in promulgating its standards for data privacy protection ${ }^{24}$ and proprietary database protection. ${ }^{25}$

Barriers to product substitution may also exist. The price elasticity of demand for law products has in the past been tied to firm location, depending on the type of law in question. The incorporation law of one state may be an acceptable substitute for that of another, because a firm need not physically move to make the substitution. However, when firms must physically move to substitute law "products," they may be locked into one legal standard by the cost of migration. The Internet itself, by increasing firm mobility, increases the ability of law "purchasers" to substitute one jurisdiction's law product for another's. By substantially lowering or eliminating that cost, the Internet destabilizes the ability of nations to collectively set an international standard for intellectual property law.

If the conditions for a stable intergovernmental cartel can be attained, the expected damage to innovation and competition will follow naturally from the principles outlined in the literature on law as a product. First, by homogenizing information law, such as national intellectual property systems, an international agreement forces international businesses to operate in a world where "one size fits all." Opportunities for jurisdictional experimentation and innovation are curtailed. ${ }^{26} \mathrm{New}$ information industries that might have arisen under innovative schemes may be stifled. Established information industries will be confined to an international norm, rather than offered the opportunity to select from a diversity of systems that which is best suited to their operation. As a corollary effect, information firms will be exposed to greater business risk because they will be less able to diversify across jurisdictions. ${ }^{27}$ Thus, the international inefficiencies resulting from an international intellectual property cartel may be no less serious than the inefficiencies resulting from lack of coordination.

\section{Law Centralization}

This view of law as a product suggests that, in some situations, certain types of defection may desirable in order to create interjurisdictional law competition, but how in other situations defection may lead to an undesirable race to externalize. If in fact cooperative strategies prove impossible or unworkable, rational competitors may have yet another option. If "horizontal" cooperation between jurisdictions proves unstable,

INSTRUMENTS-RESULTS OF THE URUGUAY ROUND vol. 31, 33 I.L.M. 81 (1994) [hereinafter TRIPS Agreement]. See Hamilton, supra note 21. Accession to TRIPS is a requirement for admission to the World Trade Organization.

${ }^{24}$ See Joel R. Reidenberg, Resolving Conflicting International Data Privacy Rules in Cyberspace, 52 STAN. L. REV. 1315 (2000) (describing EU privacy directive recipriocity requirements).

${ }^{25}$ J.H. Reichman \& Pamela Samuelson, Intellectual Property Rights in Data?, 50 VAND. L. REV. 57 (1997) (describing EU database reciprocity requirements).

${ }^{26}$ See Vaubel, supra note 14, at 29.

${ }^{27} I d$. 
the creation of a "third party" standing in a vertical relationship to the competitors may be necessary. ${ }^{28}$ Charles Tiebout recognized this in his original model by noting that where externalities exist, centralized decision-making, rather than interjurisdictional competition, may be required to achieve an efficient outcome. This principle may also be stated in game theory terms: because states know that their own rational shortterm competitive preferences will inevitably lead to their own detriment in the long term, states may choose to voluntarily surrender all or part of their decision-making power to a third party.

The third party approach is in essence the strategy adopted by the individual states of the U.S. in acquiescing to the constitutional compact that creates a centralized federal government. ${ }^{29}$ Similar benefits may be found in the federal compacts of Canada and Australia, ${ }^{30}$ and to some extent that of the European Union. ${ }^{31}$ Interestingly, it is also much the strategy adopted by the GATT signatory nations in creating the World Trade Organization (WTO). ${ }^{32}$ However, any movement toward centralization should preserve to the extent possible the benefits of interjurisdictional legal diversity. For example, in the U.S., the benefits of interstate competition have also been preserved to the extent deemed practical. ${ }^{33}$ Because competitive benefits will be lost in whichever markets are centralized, centralization must be considered a drastic measure to be taken only where no such efficiencies are to be had; that is, where externalities prevent the development of competition in the first instance. ${ }^{34}$ Therefore, international centralization for Internet-related information rights should likewise be approached with a minimalist attitude, if at all. This type of approach requires a careful consideration as to which areas truly generate externalities that would undermine information product creation, as well as careful limitation of the central authority to those areas. $^{35}$

\section{LAW AS A STANDARD}

Conceptualizing the centralization of Internet law as international cartel activity in the market for law implicates another set of economic

\footnotetext{
${ }^{28}$ See Breton, supra note 8 , at 48-49.

${ }^{29}$ See generally Jaques LeBoeuf, The Economics of Federalism and the Proper Scope of the Federal Commerce Power, 31 SAN DIEGO L. REV. 555 (1994).

${ }^{30}$ See generally M.J. SpRoule-Jones, Public Choice in Federalism in Australia AND CANADA (1975).

${ }^{31}$ See James M. Buchanan, Federalism and Individual Sovereignty, 15 CATO J. 259, 26667 (1995-96) (discussing federal structure of European Union central governance).

${ }^{32}$ See Norio Komuro, The WTO Dispute Settlement Mechanism: Coverage and Procedures of the WTO Understanding, 12 J. ARB. 81 (1995). The WTO is the trade dispute resolution mechanism resulting from the culminating round of negotiations in the multilateral General Agreement on Tariffs and Trade. See TRIPS Agreement, supra note 23; see also Uruguay Round Agreements Act, Pub. L. No. 103-465, 108 Stat. 4809 (1994) (U.S ratification and implementation of WTO agreements).

${ }^{33}$ See Richard Epstein, The Proper Scope of the Commerce Power, 73 VA. L. REV. 1387, 1454 (1987).

${ }^{34} \mathrm{Cf}$. Breton, supra note 8 , at 46.

${ }^{35}$ See Richard A. POSNER, ECONOMIC ANALYSIS OF LAW 635 (4th ed. 1992) (discussing tariff effects).
} 
models related to the standards setting for technical compatibility. "Standards" in this context may be defined as a set of technical specifications that provides common design features for a product or process. $^{36}$ The potential benefits of uniform technical standards, and the problems attending incompatible standards, are commonplace knowledge. ${ }^{37}$ As any traveler carrying an electrical appliance has discovered, the costs of non-uniform technical standards can be profound: voltage, current, and plug configuration vary enormously among different jurisdictions, requiring either expensive duplication of compatible appliances, or a panoply of adapters and transformers allowing a non-compatible appliance to interoperate with the local standards. Coordination of technical design, even among competitors, is often necessary to avoid the costs and inconvenience associated with such technical incompatibility.

As an international network, the Internet presents issues related not only to such actual compatibility of technical products but also to the virtual compatibility of legal products. ${ }^{38}$ Both sets of issues arise as a consequence of so-called "network effects." Network effects may arise in situations where the value of a system increases as users are added. ${ }^{39}$ Purchasers of such goods find the good increasingly valuable as others also purchase the good. Typically, the increased value accrues to subsequent adopters as a positive externality. ${ }^{40}$ For example, a telephone system is of relatively little value if it has only two subscribers; each subscriber can call only one other person. ${ }^{41}$ The system is of greater value if it has more subscribers because each subscriber can then communicate with many others. Those who subscribe to the system after it has accrued a large number of subscribers may obtain a more valuable service than those who subscribed early when there were few other subscribers. At the same time, the value of the service to the early subscribers grows as additional users sign on to the network.

This insight can be generalized to other types of human artifacts with shared compatibility: languages, for example, may be thought of as goods having network effects. The ability to "interoperate" internationally with a wide diversity of individuals is illustrated by the benefits of speaking Greek in the ancient Western world, Latin in the Medieval Western world, or English in the current global era. Many commentators have noted that computer operating systems tend toward a uniform standard because of the natural benefits of a uniform standard: users need only invest in learning the characteristics of the system once, technical support for a single

\footnotetext{
362 Herbert Hovenkamp et AL., IP And Antitrust: An ANALysis of ANTITRUst PRINCIPLES APPLIED TO INTELLECTUAL PROPERTY LAW $\$ 35.1$, 35-3 (2002).

37 See CARL SHAPIRO \& HAL R. VARLAN, InFORMATION Rules 229 (1999).

38 See Margaret Jane Radin, Online Standardization and the Integration of Text and Machine, 70 FORDHAM L. REV. 1125 (2002).

39 See Michael L. Katz \& Carl Shapiro, Network Externalities, Competition, and Compatibility, 75 AM. ECON. REV. 424 (1985).

${ }^{40}$ See S.J. Liebowitz \& Stephen E. Margolis, Network Externality: An Uncommon Tragedy, 8 J. ECON. PERSP. 133, 135 (1994) (distinguishing between positive and negative network effects).

${ }^{41}$ See Katz \& Shapiro, supra note 44, at 424 (citing telephones as an example of network effects); Liebowitz \& Margolis, supra note 46, at 139-40 (noting the telephone system as a paradigmatic example of network effects).
} 
standard is simple to provide, and producers of compatible software applications need only develop products to function with a single platform.

The Internet is a prime candidate for display of such network externalities: network access becomes more valuable as it becomes more ubiquitous. ${ }^{42}$ Much of the success of the Internet is due to the creation of a new type of physical network: the inter-networking protocols on which the Internet operates allow disparate types of computer hardware, running many different software systems, to interact on a single network. Thus, users with previously incompatible equipment can now join the same system and interoperate. ${ }^{43}$ Additionally, any given application run on the network may show a different kind of network effect from usage: e-mail, for example, is a more valuable service if it can be used more widely. Similarly, the World Wide Web becomes more valuable as it accumulates more reference linkages, allowing more information to be indexed and accessed.

Both types of network activities are simultaneously possible because the Internet exhibits more than one type of network effect. Katz \& Shapiro have distinguished between actual and virtual networks. ${ }^{44}$ Actual networks may be characterized as those that physically interoperate with one another; virtual networks as those that share common features without direct interoperation. To the extent that the Internet generates benefits to users by having their machines physically connected to the network, allowing interaction between users, it represents an actual network. Also, the benefits accruing from similarity of software platforms or, for that matter, from the content on the system, comprise a virtual network of shared compatibility. By providing a common technical standard, the Internet generates both types of beneficial effects.

The creation of a common standard is often beneficial, and may be critically important, where network efficiencies can be realized. At the same time, the potential downside of any standards setting process is profound. $^{45}$ Networks may also produce negative effects, as the cost of leaving the network, even when it would be socially desirable to do so, may be prohibitively high. The likelihood of being "locked-in" to an inefficient standard remains a disputed, but serious consideration. ${ }^{46}$ The concern is that once a standard is adopted, network effects may raise the cost of changing to a newer or better alternative causing the standard to become permanently entrenched. This may occur where the short-term costs of switching away from the old standard are greater than the long-term benefits of the new standard - indeed, it has been argued that development of new standards may be deterred if network effects raise the short-term

${ }^{42}$ See Mark A. Lemley \& David McGowan, Legal Implications of Network Economic Effects, 86 CAL. L. REV. 479, 551 (1998).

${ }_{43}$ See Mark A. Lemley \& Lawrence Lessig, The End of End-to-End: Preserving the Architecture of the Internet in the Broadband Era, 48 UCLA L. REV. 925 (2001).

${ }^{44}$ See Michael L. Katz \& Carl Shapiro, Systems Competition and Network Effects, 8 J. ECON. PERSP. 93, 95 (1994).

45 See Carl Shapiro, Setting Compatibility Standards: Cooperation or Collusion in EXPANDING THE BOUNDARIES OF INTELLECTUAL PROPERTY: INNOVATION POLICY FOR THE KNOWLEDGE SOCIETY 81, 88 (Rochelle Cooper Dreyfuss et. al eds., 2001).

46 See Leibowitz \& Margolis, supra note 36; S.J. Leibowitz \& Stephen E. Margolis, The Fable of the Keys, 33 J.L. \& ECON. 1 (1990). 
cost of development and deployment above the perceived savings of a new standard.

As a consequence, the development of standards carries potential risks to competition. Eventually, the prevailing standards in a networked industry might be displaced by the promulgation of new or better standards, but there is a serious danger of anti-competitive manipulation of the standards-setting process, or the standard itself, to achieve some form of market dominance. ${ }^{47}$ Standard-setting organizations may cloak anticompetitive cartel-like activity if their membership is limited and conditions permit them to control adoption of the standard. ${ }^{48}$ Either in or out of an organizational setting, it has been argued that a dominant industry player may be able to arrange tipping of the market toward a desired standard, presumably toward a proprietary standard that can be controlled or exploited by that producer. Network effects may be manipulated in these situations to lock users into the standard, frustrating new entry or technological improvement.

\section{Legal Standard Setting}

Like language or interoperable computer systems, law may also be characterized as a system with network effects, displaying the same standardization issues familiar from analysis of technological standards. ${ }^{49}$ Legal harmonization facilitates a virtual network of compatible legal standards. Efficiencies may be realized when interjurisdictional legal standards are adopted, just as they may be when interjurisdictional electrical or telecommunications standards are adopted. Such legal compatibility allows individuals and entities to invest once in learning the legal system, then apply that investment across multiple jurisdictions. Indeed, it might be said that law interoperates with law from other jurisdictions, particularly as capital, goods, and individuals interact or move across borders. Such movements or transactions may be simultaneously subject to the legal standards of multiple jurisdictions, resulting in conflicting demands on the interjurisdictional actor.

Where legal standards differ, or are incompatible, compliance with applicable law becomes expensive and uncertain. These uncertainties have long been a focus of concern for Internet-related activities, although this type of interaction is not unique to Internet activity. ${ }^{50}$ Large bodies of adaptive jurisprudence have grown up around routinely encountered questions of jurisdiction and choice of law conflicts - negotiating these complex systems of rules is a daunting task even to those knowledgeable in their mysteries, and a nearly impossible proposition to the average person or business entrepreneur. The Internet greatly facilitates such interaction, connecting individuals and institutions from different jurisdictions and

\footnotetext{
47 See Stanley M. Besen \& Joseph Farrell, Choosing How to Compete: Strategies \& Tactics in Standardization, 8 J. ECON. PERSP. 117 (1994).

48 See Mark A. Lemley, Intellectual Property Rights and Standard-Setting Organizations, 90 CAL. L. REV. 1889 (2002).

49 Cf. Radin, supra note 38.

50 See Jack Goldsmith, Against Cyberanarchy, 65 U. CHI. L. REv. 1199 (1998).
} 
raising the level of virtual movement. Perhaps more importantly, the low costs of accessing the network also makes such interactions relatively cheap, placing such them within the purview of small businesses and average citizens - no longer are transnational interactions relegated to a relatively few highly-capitalized firms. However, this new cheap access to world-wide communications also means that interjurisdictional conflicts may now become commonplace to those least likely to have expertise or skill in negotiating inconsistent legal regimes. In such circumstances, the existing framework for conflicts of law may not "scale" well. ${ }^{51}$

Thus the problem of transborder conflicts occasioned by the Internet may be characterized as a difference of scale, rather than type. But the Internet reveals an additional dimension of interjurisdictional conflicts analysis that may have gone previously unrecognized. ${ }^{52}$ The rise of Internet-based "virtual" interaction dramatically illustrates the interconnection of legal and technical networks, and implies that law interoperates with technology. The interconnected technological system of the network may be considered as an extension of the legal systems arrayed at the periphery of the net. The technological system of the network provides a common standard for interjurisdictional interoperation of diverse legal systems. Yet it must be understood that just as the network is agnostic toward the applications, platforms, or devices arrayed at its periphery, so too is it indifferent to the legal networks that it interconnects. The open architecture and end-to-end design of the network may connect devices with otherwise incompatible operating systems, or it may connect jurisdictions with otherwise incompatible legal systems: whether it is Unixbased machines interoperating with Windows-based machines or protectionist-based copyright interoperating with access-based copyright, the network treats them all the same. ${ }^{53}$ The result is that the network may bridge legal systems with radically different goals and expectations.

Most of the legal controversies surrounding the Internet may be characterized as arising out of this interconnection of incompatible legal systems, not unlike the problem faced by a traveler attempting to plug into a foreign electrical grid an appliance not intended for the local voltage or socket configuration. A variety of Internet-related controversies have erupted over online activity ranging from the promulgation of pornographic materials to the sharing of software or music files. The design of the network, lacking the natural impediments intrinsic to traditional media, actually facilitates the distribution of problematic information. ${ }^{54}$ In some cases, local reaction has centered on technological solutions, such as software filters or technological controls. In other cases, the reaction has been to amend or extend legal sanctions for the offending activity, or to

51 See Dan L. Burk, Federalism in Cyberspace Revisited, in WHO RULES THE NET? INTERNET GOVERNANCE AND JURISDICTION 119 (Adam Theirer \& Wayne Crews eds., 2003).

${ }^{52}$ Cf. Lawrence Lessig, The Law of the Horse: What Cyberlaw Might Teach, 113 HARV. L. REV. 501 (1999).

${ }^{53}$ Cf. Lemley \& Lessig, supra note 43.

${ }^{54}$ See Dan L. Burk, Cyberlaw and the Norms of Science, 1999 B.C. INT. Prop. \& TECH. F. (June 4-5, 1999), available at http://infoeagle.bc.edu/bc_org/avp/law/st_org/iptf/commentary/content/burk.html. 
implement some combination of legal and technical prohibitions. These responses to the electronic dissemination of pornography, private information, or copyrighted works are essentially attempts to either legally or technically retrofit the network to comply with the local legal regime. ${ }^{55}$

Attempts to retrofit the network to local standards via technological or cultural add-ons are in essence attempts to adapt a foreign standard to interoperate with local systems, much as the traveler may attempt to retrofit a non-conforming device to local voltage, current, or plug configuration by means of adapters and transformers. The cost of such inconvenience could be lowered, and a variety of other efficiencies realized, by establishing a single international standard for legal interoperation, at least interoperation facilitated via the Internet. On this view, the "harmonization" process for international Internet law essentially comprises a standards-setting process, establishing uniform legal standards across multiple jurisdictions.

While this approach offers the benefits of standardization, it carries with it the same dangers indicated above: there may be serious long-term costs if Internet law becomes "locked" into a single standard, particularly if dominant nations act strategically in establishing that standard. As in the case of technical standards, in standardizing law there is a real danger that creation of a dominant standard will suppress competition and entry into the market for law products. Just as firms may behave strategically in the technical standard-setting process, nations may well behave strategically in the legal standard-setting process. ${ }^{56}$ There is already some evidence that this is occurring in international harmonization regarding privacy and intellectual property, where the United States and the European Union have, respectively, largely eliminated any competing regulatory systems. ${ }^{57}$ While the international information law regime may benefit in the short run from the uniformity engineered by the US and EU dominance in these areas, there is little opportunity for displacement of these regimes by newer, possibly more innovative approaches. In this environment, such dominant law producers may well monopolize the market for Internet law for the foreseeable future.

${ }^{55} I d$.

56 Cf. Radin, supra note 38.

57 See Dan L. Burk, Privacy and Property in the Global Datasphere: International Dominance of Off-the-shelf Models for Information Control, in PROCEEDINGS OF THE FOURTH INTERNATIONAL CONFERENCE ON CULTURAL ATTITUDES TOWARD TECHNOLOGY AND COMMUNiCATION 363 (Fay Sudaweeks \& Charles Ess eds., 2004). 


\section{CONCLUSION}

I have suggested here that the costs and benefits of internationalizing Internet law can be evaluated by adapting models drawn from the economic analysis of cartel theory and standards setting, as law may be considered not only a product, but a standard. The equation of law with interoperable technical standards should hardly come as a surprise. Students of technological meaning have long held that technology comprises reified norms. ${ }^{58}$ At the same time, law is largely the formal statement of those norms. ${ }^{59}$ The normative meanings of these two cultural artifacts interact in a complex relationship, both re-shaping and reinforcing one another. More recently, legal scholars including Reidenberg and Lessig have suggested and extensively explored the interchangeability of law and of technological constraints in achieving social policy objectives. ${ }^{60}$ This conceptualization of law is in some sense the logical endpoint of the economic approach conceiving law as a product: if law is an economic good that competes with similar goods from other producers, so too is law a product that interoperates with similar products from other producers, as well as with other systems of complementary or competing products, even if they take the form of technological standards.

\footnotetext{
58 Bruno Latour, Where are the Missing Masses? The Sociology of a Few Mundane Artifacts, in Shaping Technology/Building Society: Studies in Sociotechnical ChANGE 225, 244 (Weibe E. Bijker \& John Law eds., 1992); Bruno Latour (a.k.a. Jim Johnson), Mixing Humans and Non-Humans Together: The Sociology of a Door Closer, 35 SOC. PROBS. 298, 306 (1988).

59 See Eric A. Posner, LAw AND SOCIAL NORMS (2002).

60 LAWRENCE LESSiG, CODE AND OTHER LAwS OF CYBERSPACE (1999); Joel Reidenberg, Lex Informatica: The Formulation of Information Policy Rules Through Technology, 76 TEX. L. REV. 553 (1998).
} 